\title{
Erwinia piriflorinigrans sp. nov., a novel pathogen that causes necrosis of pear blossoms
}

Correspondence

María M. López

mlopez@ivia.es

\author{
María M. López, ${ }^{1 \dagger}$ Montserrat Roselló, ${ }^{2 \dagger}$ Pablo Llop, ${ }^{1}$ Sergi Ferrer, ${ }^{3}$ \\ Richard Christen ${ }^{4}$ and Louis Gardan ${ }^{5}$
}

\author{
${ }^{1}$ Instituto Valenciano de Investigaciones Agrarias (IVIA). Ctra. Moncada-Náquera, km. 4,5, 46113 \\ Moncada, Valencia, Spain \\ ${ }^{2}$ Área de Protección Agroalimentaria, Conselleria de Agricultura, Pesca y Alimentación, Ctra. \\ Alicante-València, km. 276,5, 46460 Silla, Valencia, Spain \\ ${ }^{3}$ ENOLAB - Departament de Microbiologia i Ecologia, Universitat de València, Dr Moliner 50, \\ E-46100 Burjassot, València, Spain \\ ${ }^{4}$ UMR 6543 CNRS and Université de Nice Sophia Antipolis, Centre de Biochimie, Parc Valrose, \\ 06108 Nice CEDEX 2, France \\ ${ }^{5}$ UMR de Pavé, INRA-INH-Université, BP 60057. 42, rue G. Morel, 49071 Beaucouzé CEDEX, \\ France
}

Eight Erwinia strains, isolated from necrotic pear blossoms in València, Spain, were compared with reference strains of Erwinia amylovora and Erwinia pyrifoliae, both of which are pathogenic to species of pear tree, and to other species of the family Enterobacteriaceae using a polyphasic approach. Phenotypic analyses clustered the novel isolates into one phenon, distinct from other species of the genus Erwinia, showing that the novel isolates constituted a homogeneous phenotypic group. Rep-PCR profiles, PCR products obtained with different pairs of primers and plasmid contents determined by restriction analysis showed differences between the novel strains and reference strains of $E$. amylovora and E. pyrifoliae. Phylogenetic analysis of 16S rRNA, gpd and $\operatorname{rec} A$ gene sequences showed that the eight novel strains could not be assigned to any recognized species. On the basis of DNA-DNA hybridization studies, the novel isolates constituted a single group with relatedness values of $87-100 \%$ to the designated type strain of the group, CFBP $5888^{\top}$. Depending on the method used, strain CFBP $5888^{\top}$ showed DNA-DNA relatedness values of between 22.7 and $50 \%$ to strains of the closely related species $E$. amylovora and E. tasmaniensis. The DNA G $+C$ contents of two of the novel strains, CFBP $5888^{\top}$ and CFBP 5883, were 51.1 and 50.5 mol\%, respectively. On the basis of these and previous results, the novel isolates represent a novel species of the genus Erwinia, for which the name Erwinia piriflorinigrans sp. nov. is proposed. The type strain is CFBP $5888^{\top}\left(=\mathrm{CECT} 7348^{\top}\right)$.
Necrotic blossoms were observed in Ercolini (Coscia) and Tendral pear trees growing in Valencia, Spain, from which an unknown bacterium was consistently isolated in 1999 and during the following two years. Infected blossoms were

†These authors contributed equally to this work.

Abbreviations: ERIC, enterobacterial repetitive intergenic consensus; $\mathrm{ML}$, maximum-likelihood; MP, maximum-parsimony; $\mathrm{NJ}$, neighbourjoining; REP, repetitive extragenic palindromic; UPGMA, unweighted pair group method with arithmetic mean.

The GenBank/EMBL/DDBJ accession numbers for the 16S rRNA, gpd and recA gene sequences of strain CFBP $5888^{\top}$ are GQ405202, GQ405201 and GQ421460, respectively.

Four supplementary figures and three supplementary tables are available with the online version of this paper. similar in appearance to those affected by the disease fire blight, caused by Erwinia amylovora, but only occurred in spring and the blossoms were the only part of the trees that were affected, unlike the disease caused by E. amylovora (Roselló et al., 2002, 2006). The isolated bacterium was subjected to phenotypic and molecular characterization and, although it was recognized as belonging to the genus Erwinia, many of its characteristics differed from those of other pathogenic and non-pathogenic species of the genus Erwinia that have been isolated from pear trees, including E. amylovora (Hauben et al., 1998), Erwinia billingiae (Mergaert et al., 1999), Erwinia pyrifoliae (Kim et al., 1999) and Erwinia tasmaniensis (Geider et al., 2006). The novel isolates provoked a hypersensitivity response when they were allowed to infiltrate tobacco and tomato leaves. Their 
pathogenicity was also observed when infecting the same pear cultivars from which they were isolated but not when infecting other hosts of the family Rosaceae (Roselló et al., 2002, 2006).

The purpose of this work was to compare the novel pathogen to other members of the genus Erwinia and the family Enterobacteriaceae. Its taxonomic status was defined by using phenotypic tests, PCR amplification with several sets of primers (rep-PCR) designed from E. amylovora sequences, plasmid content and RFLP analysis after hybridization using pEA29 from E. amylovora as a probe, sequence analysis of $16 \mathrm{~S}$ rRNA, gpd and recA genes and DNA-DNA hybridization studies.

In this study, we used eight strains that were isolated from necrotic pear blossoms, five strains of E. amylovora, two strains of E. billingiae, seven strains of E. pyrifoliae, three strains of E. tasmaniensis (Supplementary Table S1) and 24 type or reference strains of phytopathogenic and saprophytic species of the genera Brenneria, Erwinia, Pantoea, Pectobacterium, Samsonia and Enterobacter. All bacteria were stored at $-80{ }^{\circ} \mathrm{C}$ in $30 \%(\mathrm{v} / \mathrm{v})$ glycerol and freezedried. Prior to performing the different analyses, the bacteria were streaked on King's medium B (King et al., 1954) and grown for $48 \mathrm{~h}$ at $25{ }^{\circ} \mathrm{C}$. The GenBank/EMBL/ DDBJ accession numbers for the 16S rRNA, gpd and recA gene sequences of the comparison strains are available in Supplementary Table S2, available in IJSEM Online.

Twenty-two conventional biochemical and physiological tests were performed and the assimilation of 99 carbon sources was determined using Biotype 100 strips (bioMérieux) on 44 pathogenic strains, excluding strains of E. tasmaniensis and E. billingiae, following previously described methods (Sutra et al., 2001; Gardan et al., 2003). All tests were performed at $28{ }^{\circ} \mathrm{C}$ except for determination of growth at different temperatures. For tests using Biotype 100 strips, results were recorded after 4 days of incubation at $28{ }^{\circ} \mathrm{C}$. A total of 121 characteristics were included in numerical taxonomic analysis of the strains. The distance matrix was calculated by using the Jaccard's coefficient and cluster analysis was carried out by using the unweighted pair group method with arithmetic mean (UPGMA) (Sneath \& Sokal, 1973). A dendrogram of the phenotypic distances among the 44 pathogenic strains was plotted (Fig. 1).

For selecting characteristics that distinguished the novel isolates from other bacterial species (E. amylovora, $E$. billingiae, E. pyrifoliae and E. tasmaniensis) commonly associated with plants of the family Rosaceae, two strains of each species were selected as reference strains for biochemical testing and the results obtained were compared with those obtained from the novel isolates. Tests using API 20 E strips (bioMérieux) were performed following the manufacturer's instructions, except that incubation was at $25{ }^{\circ} \mathrm{C}$ for $48 \mathrm{~h}$. The API $50 \mathrm{CH}$ strips were inoculated with suspensions prepared in Ayers' medium (Ayers et al., 1919) as described by Donat et al. (2007) and incubated at $25^{\circ} \mathrm{C}$ for $72 \mathrm{~h}$. Conventional tests were performed as described by Schaad et al. (2001). All tests were repeated at least twice.

PCR analyses were performed using several sets of primers to compare the eight novel isolates with the two reference strains of E. amylovora and E. pyrifoliae. Primers targeting conserved DNA sequences, such as repetitive extragenic palindromic (REP) elements (Louws et al., 1994; Stern et al., 1984), enterobacterial repetitive intergenic consensus (ERIC) sequences (Hulton et al., 1991) and BOX A, a subunit of the BOX element, sequences (Martin et al., 1992), were used as described by the indicated authors. Differences between migration patterns of the PCR products were analyzed by using BioNumerics version 6.0 (Applied Maths). Similarities were calculated using Pearson's coefficient and clustering was achieved using UPGMA. Other PCR analyses were performed using primers ams BL and amsBR, designed by Bereswill et al. (1995) from an E. amylovora chromosomal region, and AJ75 and AJ76, designed by McManus \& Jones (1995) from the plasmid pEA29 of E. amylovora, according to instructions described by the indicated authors. PCR products were visualized after electrophoresis on $1.5 \%$ agarose gels. All tests were repeated at least twice.

The plasmid contents of the eight novel isolates and two reference strains of E. amylovora and E. pyrifoliae were analyzed following the protocol of Zhou et al. (1990) and visualized by electrophoresis on a $0.8 \%$ agarose gel. Restriction analyses were performed using BamHI (Takara), and the plasmid profiles obtained were compared. Plasmid pEA29 was extracted from strain CFBP 1430, excised from the gel, purified, digested with EcoRI and labelled using a DIG High Prime DNA labelling kit I (Roche) so that it could be used as a probe with the profiles obtained by restriction analysis. The plasmid extractions and restriction digests were transferred onto nitrocellulose membranes and hybridized at $65{ }^{\circ} \mathrm{C}$. Detection was performed using a Dig Wash and Block buffer set (Roche) and the membranes were visualized using a LAS 3000 system version 1.1 imager (Fujifilm).

The 16S rRNA, gpd and recA gene sequences of two of the novel strains (CFBP 5882 and CFBP $5888^{\mathrm{T}}$ ) were sequenced by using the primer pairs $\mathrm{fd} 2$ and $\mathrm{rP} 1$ (Weisburg et al., 1991), GAP11 and GAP12c (Geider et al., 2006) and RECA1 and RECA2c (Waleron et al., 2002), respectively, according to instructions described by the indicated authors. Each novel sequence was compared against available sequences in the GenBank/EMBL/DDBJ database using BLAST searches (Altschul et al., 1990). Regions common to all these sequences were used for neighbour-joining analysis and tree reconstruction, using Kimura's two-parameter correction with 1000 bootstrap replications. Maximum-parsimony and maximum-likelihood analyses were also performed by using BioNumerics version 6.0 (Applied Maths).

DNA-DNA hybridization of the selected eight isolates was performed in two experiments. In a first experiment four reference strains of E. amylovora and the type strain of $E$. 


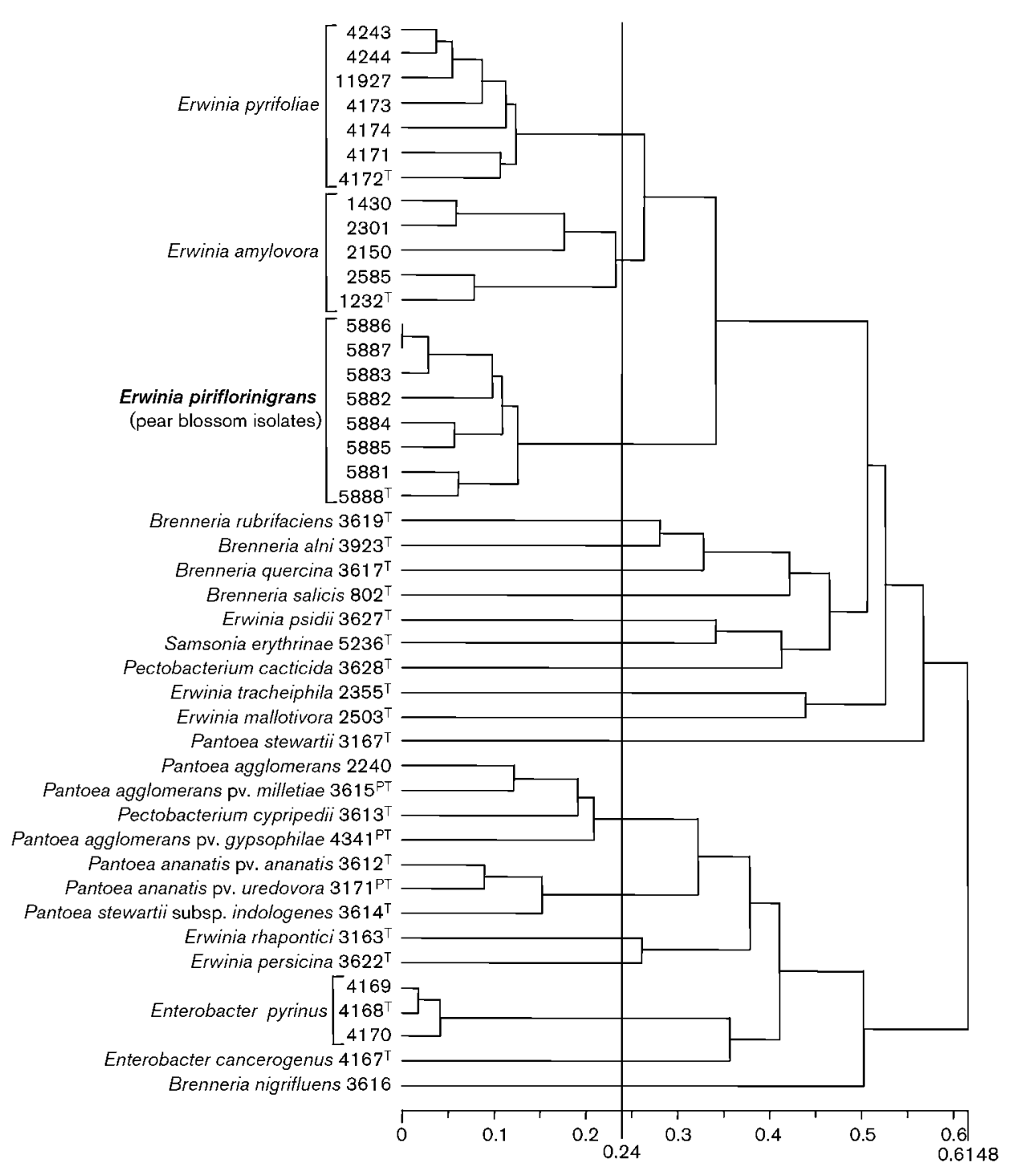

Fig. 1. Dendrogram based on UPGMA analysis of phenotypic distances among the 44 pathogenic strains studied, including the eight novel strains isolated from necrotic pear blossoms and reference strains of $E$. amylovora, E. pyrifoliae and related species. Numbers indicate CFBP accession numbers except for E. pyrifolyae strain 11927, which was obtained from the collechon of Dr Louis Gardan at INRA, Angers, France. ${ }^{\mathrm{PT}}$, Pathotype. Distance $=1-J$, where $J$ is the Jaccard's coefficient.

pyrifoliae were used. The extraction and purification of DNA was performed as described by Brenner et al. (1982). Native DNA of strain CFBP $5888^{\mathrm{T}}$ was labelled in vitro by random priming using a Megaprime kit with tritiumlabelled nucleotides (Amersham Biosciences). The S1 nuclease-trichloracetic method (Crosa et al., 1973) was used for DNA-DNA hybridization. DNA reassociation was performed at $65{ }^{\circ} \mathrm{C}$. A second experiment was performed by isolating native DNA from the type strains of $E$. amylovora, E. pyrifoliae and E. tasmaniensis and the proposed type strain of the novel isolates by using a French pressure cell (Thermo Scientific). The native DNA was purified by chromatography on hydroxyapatite as described by Cashion et al. (1977). DNA-DNA hybridization was carried out as described by De Ley et al. (1970), considering the modifications described by Huß et al. (1983), using a model Cary 100 Bio UV/VIS-spectrophotometer equipped with a Peltier-thermostatted $6 \times 6$ multicell changer and a temperature controller with an in situ temperature probe (Varian). DNA reassociation was performed in $2 \times$ saline sodium citrate buffer with $5 \%$ formamide at $68{ }^{\circ} \mathrm{C}$.

The thermal stability $\left(T_{\mathrm{m}}\right)$ of reassociated DNA was determined by using the method of Crosa et al. (1973). The DNA G + C content of strains CFBP $5888^{\mathrm{T}}$ and CFBP 5883 was determined by the thermal denaturation method of Marmur \& Doty (1962) and calculated by using the equation of Owen \& Lapage (1976). Escherichia coli K-12 CIP 54-117 (DNA G + C content $50.6 \mathrm{~mol} \%$ ) was used as a control. 
A dendrogram of phenotypic distances between the 44 strains, excluding those of E. tasmaniensis and E. billingiae, is shown in Fig. 1. At a distance of 0.24, six phenons and 14 unclustered strains were observed. Phenon 1 corresponded to seven strains of E. pyrifoliae pathogenic to Asian pear trees (Pyrus pyrifolia Nakai). Phenon 2 clustered five strains of $E$. amylovora. Phenon 3 clustered the eight novel strains isolated from pear blossoms, which constituted a homogeneous phenotypic group. The unclustered strains and those that clustered into three other phenons comprised type or reference strains of the genera Erwinia, Pectobacterium, Pantoea, Samsonia, Brenneria and Enterobacter.

The phenotypic characteristics that differentiated the novel strains from other members of the genus Erwinia ( $E$. amylovora, E. billingiae, E. pyrifoliae and E. tasmaniensis), isolated from plant hosts of the family Rosaceae, are shown in Table 1. The selected tests also distinguished the novel isolates from E. amylovora and E. pyrifoliae, both pathogens of rosaceous plants. Moreover, some phenotypic characters of the studied isolates were also different enough (Geider et al., 2006) to differentiate them from non-pathogenic species E. billingiae and E. tasmaniensis (Table 1). The assimilation of adonitol was positive in the novel strains, negative in E. amylovora, E. pyrifoliae and E. tasmaniensis and variable in E. billingiae. In addition, the strong hydrolysis of Tween 20 and acid production from Draffinose seemed to distinguish the novel strains from other members of the genus Erwinia.

The fingerprint profiles generated with ERIC, REP and BOX primer sets showed the same banding patterns between the eight novel isolates but different profiles were seen when these were compared to the patterns obtained with the reference strains of E. amylovora and E. pyrifoliae.

Table 1. Phenotypic characteristics that differentiate eight novel strains isolated from necrotic pear blossoms from strains of related species of the genus Erwinia

Taxa: 1, E. piriflorinigrans sp. nov.; 2, E. amylovora; 3, E. billingiae; 4, E. pyrifoliae; 5, E. tasmaniensis. Two strains were tested for all taxa. + , Positive; -, negative; $\mathrm{w}$, weakly positive; $\mathrm{v}$, variable.

\begin{tabular}{|c|c|c|c|c|c|}
\hline Characteristic & 1 & 2 & 3 & 4 & 5 \\
\hline Gelatinase & - & + & + & $\mathrm{V}$ & - \\
\hline Nitrate reduction & - & - & + & - & - \\
\hline Tween 20 hydrolysis & + & - & $\mathrm{W}$ & - & - \\
\hline \multicolumn{6}{|l|}{ API $20 \mathrm{E}$ : } \\
\hline Arabinose & + & - & + & - & - \\
\hline$\beta$-Galactosidase & + & - & + & - & + \\
\hline \multicolumn{6}{|l|}{ API $50 \mathrm{CH}:$} \\
\hline D-Adonitol & + & - & $\mathrm{v}$ & - & - \\
\hline D-Arabitol & - & - & + & - & - \\
\hline Arbutin & - & - & + & - & - \\
\hline L-Fucose & - & - & + & - & - \\
\hline Gentiobiose & + & - & + & - & - \\
\hline D-Raffinose & + & - & - & - & - \\
\hline
\end{tabular}

Resulting dendrograms clearly grouped the eight novel isolates in a cluster distinct from those formed by reference strains of E. amylovora and E. pyrifoliae. A combined dendrogram for rep-PCR (ERIC, BOX and REP-PCR) is provided as Supplementary Fig. S1, available in IJSEM Online. No amplification was obtained from plasmid pEA29 sequences using the primers AJ75 and AJ76 (McManus \& Jones, 1995). However, results were positive when using the primers for the amplification of chromosomal ams BL and amsBR gene sequences (Bereswill et al., 1995).

The plasmid pattern of each of the eight novel isolates provided only one band, similar in size to the band obtained from the $29 \mathrm{~kb}$ plasmid of E. amylovora, except for one strain (CFBP 5887) that harboured two plasmids, one of $\sim 29 \mathrm{~kb}$ and another of $\sim 5 \mathrm{~kb}$. Restriction analyses with BamHI showed that the profiles obtained with the plasmids from the eight novel isolates were identical to each other but were different to those of reference strains of E. amylovora and E. pyrifoliae. Nevertheless, hybridizations using pEA29 as probe on these isolates were positive for some of the plasmid fragments as well as for some fragments of two reference strains of E. pyrifoliae (Supplementary Fig. S2).

According to the phylogenetic analysis of $16 \mathrm{~S}$ rRNA, $g p d$ and $r e c A$ gene sequences of two of the novel strains, strains CFBP 5882 and CFBP $5888^{\mathrm{T}}$ represent a novel bacterial species within the genus Erwinia (Fig. 2 and Supplementary Figs S3 and S4). The 16S rRNA gene sequence similarities between strain CFBP $5888^{\mathrm{T}}$ and type strains of the genus Erwinia were as follows: $97.40 \%$ with E. tasmaniensis Et $1 / 99^{\mathrm{T}}$, $97.25 \%$ with E. amylovora $\mathrm{NCPPB} 683^{\mathrm{T}}, 97.18 \%$ with Erwinia toletana $\mathrm{A} 37^{\mathrm{T}}, 97.09 \%$ with E. pyrifoliae CFBP $4172^{\mathrm{T}}, 97.03 \%$ with Erwinia rhapontici ATCC $29283^{\mathrm{T}}$, $96.59 \%$ with Erwinia persicina ATCC $35998^{\mathrm{T}}$ and $96.36 \%$ with E. billingiae LMG $2613^{\mathrm{T}}$. A more detailed analysis showed that these sequences form a very robust clade that is distinct from described species of the genus Erwinia. Accordingly, the phylogenetic analysis of the 16S rRNA, gpd and recA gene sequences strongly suggests that these two strains represent a novel species within the genus Erwinia.

Results of DNA-DNA hybridizations are shown in Supplementary Table S3. The eight necrotic pear-blossom isolates were $87-100 \%$ related to strain CFBP $5888^{\mathrm{T}}$. The five strains of E. amylovora and E. pyrifoliae were 32-50\% related to strain CFBP $5888^{\mathrm{T}}$, with $\Delta T_{\mathrm{m}}$ values for the type strains of these species of 8.5 and $6.0{ }^{\circ} \mathrm{C}$, respectively, in the first experiment. In a second experiment, using a different methodology, type strains of E. amylovora, E. pyrifoliae and E. tasmaniensis were 22.7, 39.0 and $38.4 \%$ related, respectively, to strain CFBP $5888^{\mathrm{T}}$. Thus, based on DNA hybridization values, the necrotic pear-blossom isolates constituted a single group and, consequently, represent a novel species of the genus Erwinia. Strains CFBP $5888^{\mathrm{T}}$ and CFBP 5883 had DNA G+C contents of 51.1 and $50.5 \mathrm{~mol} \%$, respectively. 


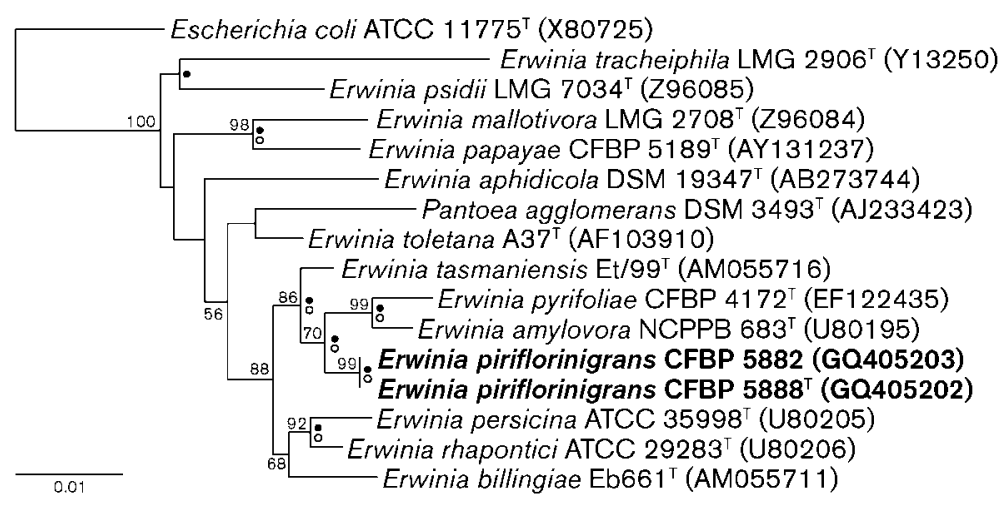

Fig. 2. Phylogenetic tree based on $16 \mathrm{~S}$ rRNA gene sequences of strains CFBP $5888^{\top}$ and CFBP 5882, isolated from necrotic pear blossoms, and closely related species and reconstructed using the neighbour-joining method. Solid and open circles indicate branches of the tree that were also recovered in trees reconstructed using the maximumlikelihood and maximum-parsimony methods, respectively. Bootstrap percentages $>50 \%$ (based on 1000 replications) are indicated at branch points. Bar, 0.01 substitutions per nucleotide position. Escherichia coli ATCC $11775^{\top}$ was used as an outgroup.
All the comparative analyses support the conclusion that the eight isolates constitute a novel species of the genus Erwinia. On the basis of phenotypic analysis, the novel isolates seemed to be metabolically more active than strains of E. amylovora and E. pyrifoliae and could be differentiated from these species, as well as from E. billingiae and E. tasmaniensis, by the results of a set of eleven tests. The novel isolates could also be differentiated from $E$. amylovora and E. pyrifoliae on the basis of other features, including serological properties and fatty acid profiles as previously described (Roselló et al., 2006). As it is generally accepted that for an isolate to belong to a given species there must be at least $80-85 \%$ sequence similarity based on analysis with UPGMA (Wayne et al., 1987; Janda \& Abbott, 2002), the isolates under study could not be assigned to another phenon.

The results obtained from different molecular analyses mostly showed differences between the novel strains and strains of E. amylovora and E. pyrifoliae, but there were also some similarities. Patterns obtained from the amplification of sequences that are repeated along the genome (rep-PCR) demonstrated these differences and supported the conclusion that the novel isolates from necrotic pear blossoms were significantly different from strains of E. amylovora and E. pyrifoliae.

PCR analyses from this study and from a previous study (Roselló et al., 2006) showed negative results for the novel isolates with the primers targeting plasmid pEA29 of E. amylovora (Bereswill et al., 1992; Llop et al., 2000; McManus \& Jones, 1995) and with some primers based on chromosomal sequences of E. amylovora, such as primers Ea71/72 (Guilford et al., 1996). Nevertheless, with primers such as amsBL and amsBR (Bereswill et al., 1995) and $\mathrm{EaF}$ and $\mathrm{EaR}$ (Maes et al., 1996) targeting other chromosomal sequences, the amplification was positive, indicating similarities in some chromosomal sequences. Moreover, when the strains of Erwinia isolated in Japan and those of E. pyrifoliae were analyzed by PCR using primers based on sequences of the amylovoran synthesis gene (ams) region of E. amylovora (Bereswill et al., 1995), no amplified products were obtained (Kim et al., 2001), thus supporting the differences between these groups of strains.

Analysis of the plasmid content and subsequent hybridizations have shown the presence of one plasmid in the novel isolates, which is of a similar size, not only to pEA29, but also to one of the plasmids present in strains of E. pyrifoliae. Restriction profiles of the plasmids analyzed using BamHI were different to those of pEA29 but hybridization using pEA29 as a probe provided similar results to those described in previous studies (Kim et al., 2001; McGhee et al., 2002; Maxson-Stein et al., 2003), in which related sequences were found in plasmids from strains of E. pyrifoliae and E. amylovora and the strains of Erwinia isolated in Japan. This suggests that some common plasmid DNA sequences can be found in these pathogenic species from different and distant locations.

Finally, 16S rRNA, gpd and recA gene sequencing and DNA-DNA hybridization studies on the novel isolates confirmed the identification of these isolates as a novel species, the results being in agreement with the recommended standards of quantitative differentiation (Wayne et al., 1987; Janda \& Abbott, 2002).

The polyphasic approach used to identify these isolates, in this and in a previous study (Roselló et al., 2006), included a combination of phenotypic methods (biochemical tests, fatty acid profiles, serological properties and numerical analysis) and genotypic methods (rep-PCR profiles, PCR products with several primers, plasmid content and RFLP, 16S rRNA, gpd and recA gene sequencing, analysis of DNA G $+\mathrm{C}$ content and DNADNA hybridization), the results of which fulfilled the recommended criteria reported as necessary for the definition of a novel species (Stackebrandt et al., 2002). On the basis of these and previous results, the novel isolates represent members of a novel species of the genus Erwinia, for which the name Erwinia piriflorinigrans sp. nov. is proposed. 


\section{Description of Erwinia piriflorinigrans sp. nov.}

Erwinia piriflorinigrans (pi.ri.flo.ri.ni'grans. L. n. pirus pear tree; L. n. flos -floris flower; L. part. adj. nigrans blackened, darkened; N.L. part. adj. piriflorinigrans blackened pear blossom, from which the type strain was isolated).

Cells are Gram-reaction-negative, facultatively anaerobic, non-spore-forming, motile, straight rods. Glucose is oxidized and fermented without producing gas in HughLeifson's medium (Hugh \& Leifson, 1953). Catalasepositive and oxidase-negative. Nitrates are not reduced. Grows on King's medium B (King et al., 1954) producing non-fluorescent, circular, white, slightly convex, mucoid colonies, $2-3 \mathrm{~mm}$ in diameter with regular margins after $48 \mathrm{~h}$ at $25^{\circ} \mathrm{C}$. Produces convex colonies on Sucrose Nutrient agar and CCT media (Ishimaru \& Klos, 1984) and produces levan. Does not hydrolyse arginine in anaerobiosis. Urease-negative. Does not use calcium galacturonate in Sutton's medium (Sutton, 1957), or show ice nucleation activity. Hydrolyses Tween 20 but not Tween 80 or gelatin. Reduces sugars from sucrose and produces acetoin. Grows in nutrient broth at 25 and $30{ }^{\circ} \mathrm{C}$ but not at $37{ }^{\circ} \mathrm{C}$ or higher. In the API $20 \mathrm{E}$ (bioMérieux) system, tests are positive for $\beta$-galactosidase activity, citrate and acetoin production and acidification of glucose, mannitol, myoinositol, sucrose, melibiose and arabinose but negative for arginine dihydrolase and lysine and ornithine decarboxylase activities, acid production from sodium thiosulfate, urease, tryptophan deaminase, indole, gelatin and acidification of sorbitol, rhamnose and amygdalin. In the API $50 \mathrm{CH}$ (bioMérieux) (Roselló et al., 2006) and Biotype 100 systems (bioMérieux) (this study), glycerol, L-arabinose, ribose, D-xylose, adonitol, galactose, D-glucose, D-fructose, myo-inositol, mannitol, $\mathrm{N}$-acetylglucosamine, melibiose, sucrose, trehalose, raffinose, $\beta$-gentiobiose methyl- $\alpha$-glucoside, D-fucose, D- and L-alanine, L-serine, L-proline, fumarate, D-gluconate, L-glutamate, L-malate and succinate are utilized. The predominant fatty acids are (in decreasing order): $\mathrm{C}_{16: 0}$, summed feature $3\left(\mathrm{C}_{16: 1} \omega 7 c\right.$ and/or iso$\left.\mathrm{C}_{15: 0} 2-\mathrm{OH}\right)$, summed feature $2\left(\mathrm{C}_{14: 0} 3-\mathrm{OH}\right.$ and/or iso$\left.\mathrm{C}_{16: 1} \mathrm{I}\right), \mathrm{C}_{18: 1} \omega 7 c, \mathrm{C}_{14: 0}$ and $\mathrm{C}_{12: 0}, \mathrm{C}_{17: 0}$ cyclo, unknown fatty acids of equivalent chain-lengths (ECL) 14502 and 13 597, $\mathrm{C}_{18: 0}, \mathrm{C}_{15: 0}, \mathrm{C}_{17: 0}$, and, as a minor component, $\mathrm{C}_{18: 1} \omega 5 c$ (Roselló et al., 2006). Does not react with a mixture of commercially available mAbs (IVIA $3 \mathrm{~B}+$ IVIA $5 \mathrm{H}$; PlantPrint Diagnostics) designed for the detection of $E$. amylovora in a DASI-ELISA protocol (Roselló et al., 2006).

The type strain, CFBP $5888^{\mathrm{T}}\left(=\right.$ CECT $\left.7348^{\mathrm{T}}\right)$, was isolated from, and causes necrosis of, pear blossoms of Ercolini (Coscia) and Tendral pear trees and elicits a hypersensitive reaction when inoculated in tobacco and tomato leaves.

Strains show identical rep-PCR profiles, which are different from the profiles obtained with E. amylovora or $E$. pyrifoliae. Amplification is observed when using the primers EaF-EaR (Maes et al., 1996), whose targets are $23 \mathrm{~S}$ rRNA gene sequences, and primers from other chromosomal sequences such as amsBL-amsBR (Bereswill et al., 1995). PCR analyses give negative results using the $E$. amylovora pEA29 primers (Bereswill et al., 1992; Llop et al., 2000; McManus \& Jones, 1995) and using other primers based on E. amylovora chromosomal sequences, such as the Ea71 primers (Guilford et al., 1996). The isolates contain a plasmid of similar size to the pEA29 of E. amylovora. The DNA G + C content is $50-51 \mathrm{~mol} \%$.

\section{Acknowledgements}

We are grateful to $\mathrm{M}^{\mathrm{a}}$ Luisa Palazón and Javier Martínez Calvo for their help in naming the novel species, to Clara Morente, Julia Romaguera, Lourdes Rius and Roland Chartier for technical assistance and to Jean-Pierre Paulin for helpful discussions. This work was supported by grants from projects CICYT AGL2001-2349C03-02 and CICYT AGL2005-06982/AGR. P.L. had a contract from INIA-CCAA (Ministry of Education and Science, Spain) with funding from the European Union (Social European Funding). The work was performed in the framework of COST 864.

\section{References}

Altschul, S. F., Gish, W., Miller, W., Myers, E. W. \& Lipman, D. J. (1990). Basic local alignment search tool. J Mol Biol 215, 403-410.

Ayers, S. H., Rupp, P. \& Johnson, W. T. (1919). A study of the alkaliforming bacteria in milk. USDA Bulletin $\mathbf{7 8 2}$.

Bereswill, S., Pahl, A., Belleman, P., Berger, F., Zeller, W. \& Geider, K. (1992). Sensitive and species-specific detection of Erwinia amylovora by PCR analysis. Appl Environ Microbiol 58, 3522-3526.

Bereswill, S., Bugert, P., Bruchmüller, I. \& Geider, K. (1995). Identification of the fire blight pathogen, Erwinia amylovora, by PCR assays with chromosomal DNA. Appl Environ Microbiol 61, 2636-2642.

Brenner, D. J., McWhorter, A. C., Knutson, J. K. \& Steigerwalt, A. G. (1982). Escherichia vulneris: a new species of Enterobacteriaceae associated with human wounds. J Clin Microbiol 15, 1133-1140.

Cashion, P., Holder-Franklin, M. A., McCully, J. \& Franklin, M. (1977). A rapid method for the base ratio determination of bacterial DNA. Anal Biochem 81, 461-466.

Crosa, J. H., Brenner, D. J. \& Falkow, S. (1973). Use of a single-strand specific nuclease for analysis of bacterial and plasmid deoxyribonucleic acid homo- and heteroduplexes. J Bacteriol 115, 904-911.

De Ley, J., Cattoir, H. \& Reynaerts, A. (1970). The quantitative measurement of DNA hybridization from renaturation rates. Eur J Biochem 12, 133-142.

Donat, V., Biosca, E. G., Peñalver, J. \& López, M. M. (2007). Exploring diversity among Spanish strains of Erwinia amylovora and possible infection sources. J Appl Microbiol 103, 1639-1649.

Gardan, L., Gouy, C., Christen, R. \& Samson, R. (2003). Elevation of three subspecies of Pectobacterium carotovorum to species level: Pectobacterium atrosepticum sp. nov., Pectobacterium betavasculorum sp. nov. and Pectobacterium wasabiae sp. nov. Int J Syst Evol Microbiol 53, 381-391.

Geider, K., Auling, G., Du, Z., Jakovljevic, V., Jock, S. \& Völksch, B. (2006). Erwinia tasmaniensis sp. nov., a non-phytopathogenic bacterium from apple and pear trees. Int J Syst Evol Microbiol 56, 2937-2943.

Guilford, P. J., Taylor, R. K., Clark, R. G., Hale, C. N. \& Forster, R. L. S. (1996). PCR-based techniques for the detection of Erwinia amylovora. Acta Hort 411, 53-56. 
Hauben, L., Moore, E. R. B., Vauterin, L., Steenackers, M., Mergaert, J., Verdonck, L. \& Swings, J. (1998). Phylogenetic position of phytopathogens within the Enterobacteriaceae. Syst Appl Microbiol 21, 384-397.

Hugh, R. \& Leifson, E. (1953). The taxonomic significance of fermentative versus oxidative metabolism of carbohydrates by various Gram negative bacteria. J Bacteriol 66, 24-26.

Hulton, C. S. J., Higgins, C. F. \& Sharp, P. M. (1991). ERIC sequences: a novel family of repetitive elements in the genomes of Escherichia coli, Salmonella typhimurium and other enterobacteria. Mol Microbiol 5, 825-834.

Huß, V. A. R., Festl, H. \& Schleifer, K. H. (1983). Studies on the spectrophotometric determination of DNA hybridization from renaturation rates. Syst Appl Microbiol 4, 184-192.

Ishimaru, C. \& Klos, E. J. (1984). New medium for detecting Erwinia amylovora and its use in epidemiological studies. Phytopatology 74, 1342-1345.

Janda, J. M. \& Abbott, S. L. (2002). Bacterial identification for publication: when is enough enough? J Clin Microbiol 40, 1887-1891.

Kim, W. S., Gardan, L., Rhim, S. L. \& Geider, K. (1999). Erwinia pyrifoliae sp. nov., a novel pathogen that affects Asian pear trees (Pyrus pyrifolia Nakai). Int J Syst Bacteriol 49, 899-906.

Kim, W. S., Hildebrand, M., Jock, S. \& Geider, K. (2001). Molecular comparison of pathogenic bacteria from pear trees in Japan and the fire blight pathogen Erwinia amylovora. Microbiology 147, 2951-2959.

King, E. O., Ward, M. K. \& Raney, D. E. (1954). Two simple media for the demonstration of pyocyanin and fluorescin. J Lab Clin Med 44, 301-307.

Llop, P., Bonaterra, A., Peñalver, J. \& López, M. M. (2000). Development of a highly sensitive nested-PCR procedure using a single closed tube for detection of Erwinia amylovora in asymptomatic plant material. Appl Environ Microbiol 66, 2071-2078.

Louws, F. J., Fulbright, D. W., Stephens, C. T. \& de Bruijn, F. J. (1994). Specific genomic fingerprints of phytopathogenic Xanthomonas and Pseudomonas pathovars and strains generated with repetitive sequences and PCR. Appl Environ Microbiol 60, 2286-2295.

Maes, M., Garbeva, P. \& Crepel, C. (1996). Identification and sensitive endophytic detection of the fire blight pathogen Erwinia amylovora with $23 \mathrm{~S}$ ribosomal DNA sequences and the polymerase chain reaction. Plant Pathol 45, 1139-1149.

Marmur, J. \& Doty, P. (1962). Determination of the base composition of deoxyribonucleic acid from its thermal denaturation temperature. J Mol Biol 5, 109-118.

Martin, B., Humbert, O., Camara, M., Guenzi, E., Walker, J., Mitchell, T., Andrew, P., Prudhomme, M., Alloing, G. \& other authors (1992). A highly conserved repeated DNA element located in the chromosome of Streptococcus pneumoniae. Nucleic Acids Res 20, 3479-3483.

Maxson-Stein, K., McGhee, G. C., Smith, J. J., Jones, A. L. \& Sundin, G. W. (2003). Genetic analysis of a pathogenic Erwinia sp. isolated from pear in Japan. Phytopathology 93, 1393-1399.

McGhee, G. C., Schnabel, E. L., Maxson-Stein, K., Jones, B., Stromberg, V. K., Lacy, G. H. \& Jones, A. L. (2002). Relatedness of chromosomal and plasmid DNAs of Erwinia pyrifoliae and Erwinia amylovora. Appl Environ Microbiol 68, 6182-6192.

McManus, P. S. \& Jones, A. L. (1995). Detection of Erwinia amylovora by nested PCR and PCR-dot-blot and reverse-blot hybridizations. Phytopathology 85, 618-623.

Mergaert, J., Hauben, L., Cnockaert, M. C. \& Swings, J. (1999). Reclassification of non-pigmented Erwinia herbicola strains from trees as Erwinia billingiae sp. nov. Int J Syst Evol Microbiol 49, 337-383.

Owen, R. J. \& Lapage, S. P. (1976). The thermal denaturation of partly purified bacterial deoxyribonucleic acid and its taxonomic applications. J Appl Bacteriol 41, 335-340.

Roselló, M., García-Vidal, S., Tarín, A., Llop, M. T., Gorris, V., Donat, R., Chartier, J. P., Paulin, L., Gardan, J. \& other authors (2002). Characterization of an Erwinia sp. isolated from necrotic pear blossoms in Valencia, Spain. Acta Hort 590, 139-142.

Roselló, M., Peñalver, J., Llop, P., Gorris, M. T., Chartier, R., García, F., Montón, C., Cambra, M. \& López, M. M. (2006). Identification of an Erwinia sp. different from Erwinia amylovora and responsible for necrosis on pear blossoms. Can J Plant Pathol 28, 30-41.

Schaad, N. W., Jones, J. B. \& Chun, W. (2001). Laboratory guide for identification of plant pathogenic bacteria. St. Paul, MN: APS Press.

Sneath, P. H. A. \& Sokal, R. R. (1973). Numerical taxonomy: the principles and practice of numerical classification. San Francisco: Freeman.

Stackebrandt, E., Frederiksen, W., Garrity, G. M., Grimont, P. A., Kämpfer, P., Maiden, M. C., Nesme, X., Rosselló-Mora, R., Swings, J. $\&$ other authors (2002). Report of the ad hoc committee for the reevaluation of the species definition in bacteriology. Int J Syst Evol Microbiol 52, 1043-1047.

Stern, M. J., Ames, G. F., Smith, N. H., Robinson, E. C. \& Higgins, C. F. (1984). Repetitive extragenic palindromic sequences: a major component of the bacterial genome. Cell 37, 1015-1026.

Sutra, L., Christen, R., Bollet, C., Simoneau, P. \& Gardan, L. (2001). Samsonia erythrinae gen. nov., sp. nov., isolated from bark necrotic lesions of Erythrina sp., and discrimination of plant-pathogenic Enterobacteriaceae by phenotypic features. Int J Syst Evol Microbiol 51, 1291-1304.

Sutton, D. D. (1957). Physiology and taxonomy of the genus Erwinia. $\mathrm{PhD}$ thesis. University of California, Davis, California.

Waleron, M., Waleron, K., Podhajska, A. J. \& kojkowska, E. (2002). Genotyping of bacteria belonging to the former Erwinia genus by PCR-RFLP analysis of a recA gene fragment. Microbiology 148, 583595.

Wayne, L. G., Brenner, D. J., Colwell, R. R., Grimont, P. A. D., Kandler, O., Krichevsky, M. I., Moore, L. H., Moore, W. E. C., Murray, R. G. E. \& other authors (1987). Report of the ad hoc committee on reconciliation of approaches to bacterial systematics. Int J Syst Bacteriol 37, 463-464.

Weisburg, W. G., Barns, S. M., Pelletier, D. A. \& Lane, D. J. (1991). $16 \mathrm{~S}$ ribosomal DNA amplification for phylogenetic study. J Bacteriol 173, 697-703.

Zhou, C., Yang, Y. \& Jong, A. Y. (1990). Mini-prep in ten minutes. Biotechniques 8, 172-173. 